\title{
METHOD FOR COMPENSATION OF EYE MOVEMENTS IN ADAPTIVE OPTICS
}

\author{
V. Karitans ${ }^{1}$, M. Ozolinsh ${ }^{1,2}$ \\ ${ }^{1}$ Department of Ferroelectrics, Institute of Solid State Physics, University of Latvia \\ ${ }^{2}$ Department of Optometry and Vision Science, University of Latvia \\ 8 Kengaraga Str., Riga, LV-1063, LATVIA
}

The benefit of correction of aberrations in the human eye with adaptive optics is strongly reduced by eye movements. Although devices for compensation of eye movements have already been developed, these are very advanced and expensive. We are working on the development of a novel method for eye movement compensation based on the detection of a corneal reflex by a linear profile sensor. Electronic circuits for controlling the profile sensor and stepper motors have already been designed. Next, a circuit must be designed so that the profile sensor controls the stepper motor. One of the shortcomings of this method is that a stepper motor runs at low speed. Another shortcoming is that the profile sensor operates in only one dimension. However, these problems can be solved by using a two-dimensional profile sensor and piezo-mounts working at much higher frequencies.

Key words: adaptive optics, retinal tracking, retinal image.

\section{INTRODUCTION}

For successful application of adaptive optics (AO) in vision science the compensation of eye movements is essential because of two reasons. First, stable
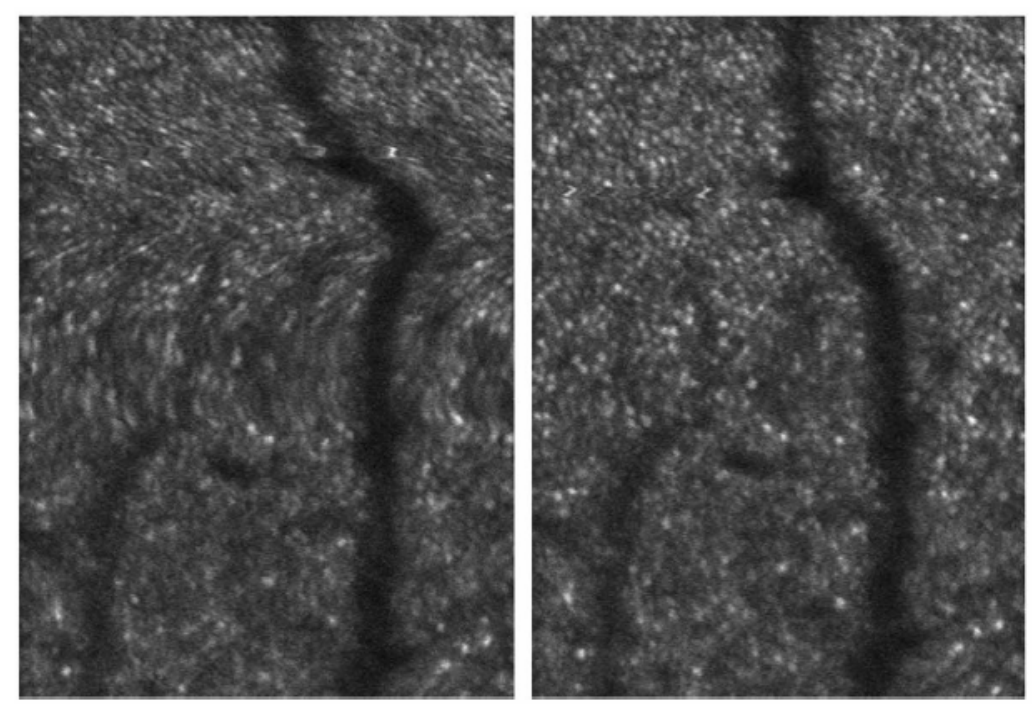

Fig. 1. Role of eye movements in retinal imaging. Both the left and the right image are acquired by using adaptive optics, and individual photoreceptors can be distinguished. In the left image significant blur due to eye movements is visible. 
gaze is very important for a static pattern of dots on a Shack-Hartmann wavefront sensor so that aberrations can be calculated correctly. Second, in AO systems the telescopic constructions with large magnification are used, due to which even small rapid eye movements cause significant blurring of retinal images (see Fig. 1). The only way to compensate eye movements is to adapt to them, because the rapid movements (called saccades) cannot be controlled voluntarily. A method for compensation of saccadic eye movements has already been developed and described [1]. Briefly, reflectometers detect a scanning laser beam reflected from a specific retinal structure. The error signals generated drive two mutually perpendicular galvanometric mirrors to maintain one and the same direction of the gaze. These devices can work at high frequency - even over $100 \mathrm{~Hz}$.

We have developed a novel method for compensation of eye movements. As distinct from the previous methods, we use the corneal reflex instead of the retinal one. Further, more detailed description is given.

\section{EXPERIMENTAL}

The method is based on the use of a linear profile sensor S9226 (Hamamatsu corporation) (see Fig. 2) [2]. The profile sensor is particularly useful for detecting a light spot and its movement. In our method we use the reflection from the anterior surface of the cornea for determining the direction of gaze, which can be done by identifying the most intense pixel of the whole array.

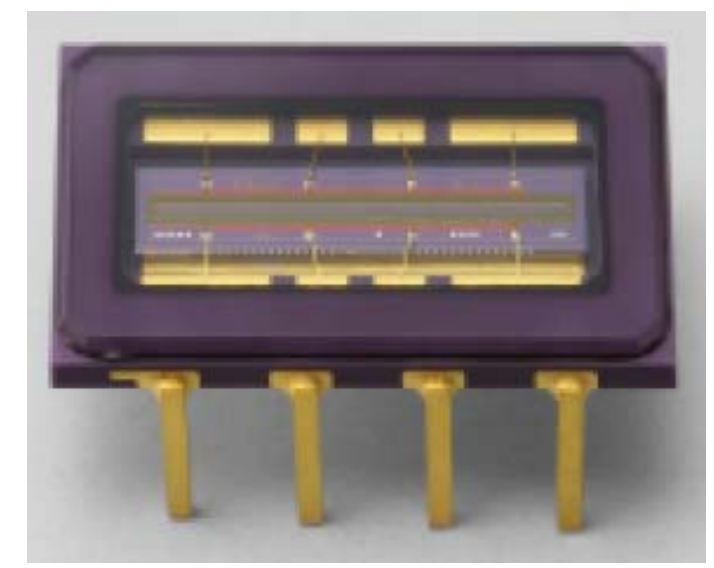

Fig. 2. Linear profile sensor S9226 (Hamamatsu corporation) for detection of moving light spots. The sensor consists of $1 \times 1024$ pixel array. Each pixel outputs an analog video signal.

In Fig. 3 the sequence of the previously mentioned steps is shown schematically. If the path of the light reflected from the cornea fully coincides with the AO system's optical axis, the most intense pixel of the whole pixel array is the central pixel (Fig. $3 A$ ). The direction of the beam reflected from the cornea is strongly dependent on the angle by which the eye has turned. Generally, if the eye has turned away by some angle a pixel other than the central one will be the most intense. The path of the reflected beam is now marked by a dashed line (Fig. $3 B$ ). The next task is to change the angular position of mirror M1 so that the path of the reflected beam is parallel to the optical axis of the AO system. When this is achieved, lens $\mathrm{L}$ will focus the reflected beam on the central pixel of the profile sensor so that it will 
be the most intense pixel again (Fig. 3C). However, this condition is necessary but not sufficient for full alignment of the path of the reflected beam and the optical axis of the AO system. After that, translation movement of the beam-splitter BS-1 is also required to align the path of the reflected beam with the mentioned optical axis. When the optoswitch OS is illuminated, the translation movement of beamsplitter BS-1 is stopped, and the path of the reflected beam is aligned with the optical axis of the AO system. The reflected beam is further directed towards the AO system by beam-splitter BS-2 and mirror M-2 (Fig. 3D).

A

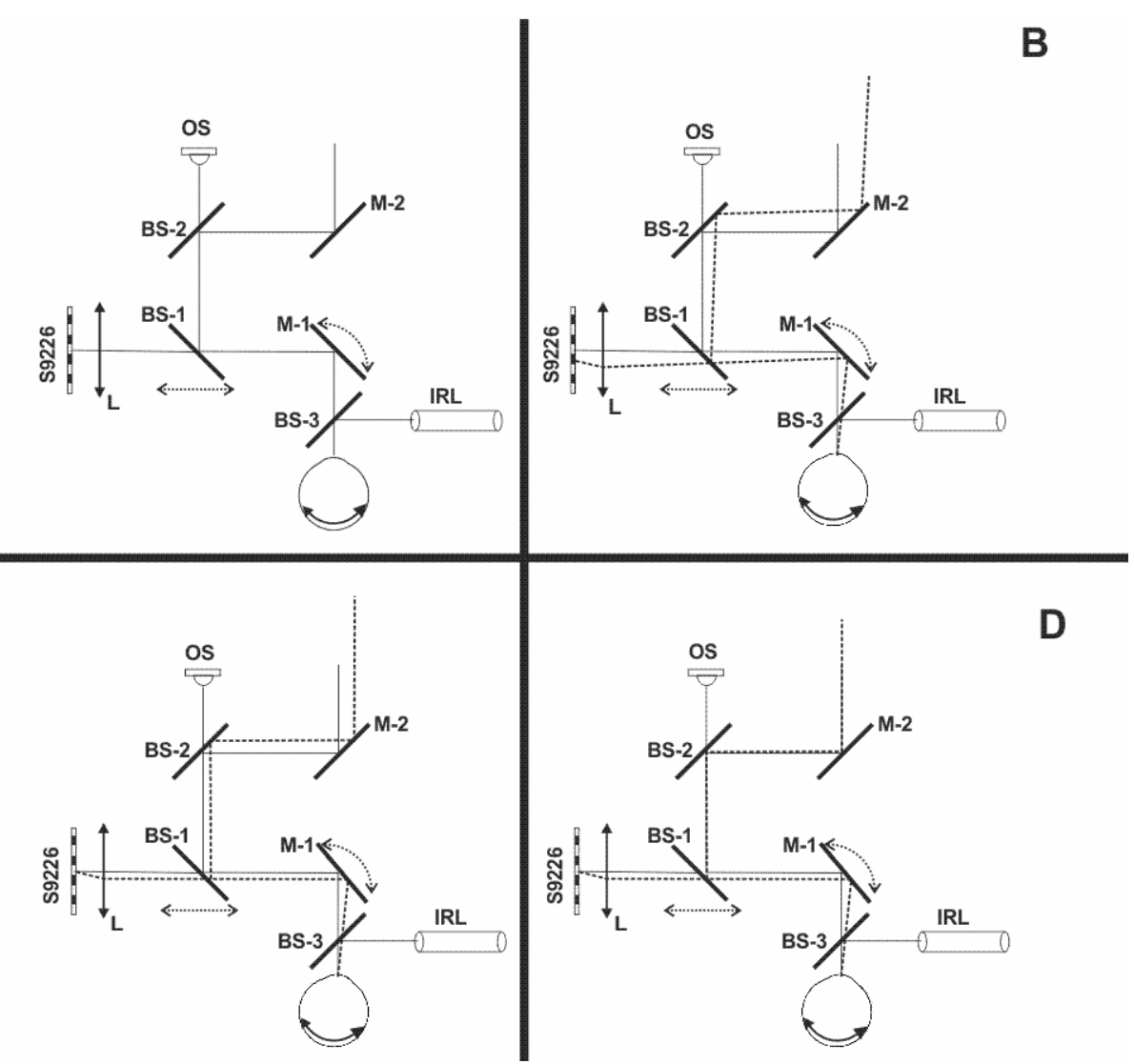

Fig. 3. Sequence of steps in compensating eye movements. $(A)$ The ideal case when path of the beam reflected from the cornea coincides with the optical axis of the AO system (solid line). $(B)$ The eye has turned by some angle rightwards. Now the reflected beam is that marked by the dashed line. $(C)$ The mirror has turned around its vertical axis so that the reflected beam becomes parallel to the optical axis of the AO system (the path of the reflected beam and the AO system's optical axis does not yet coincide). (D) After translation movement of beam-splitter BS-1 the reflected beam coincides with the optical axis of the AO system.

The cornea is illuminated by an infrared laser (IRL) at wavelength $\lambda=830 \mathrm{~nm}$ emitting power $P=30 \mathrm{~mW}$. Upon reflection and due to passing through several elements the initial power is lost and at the cornea is about $100 \mu \mathrm{W}$. The motorized translation and rotational stages are provided by Lithuanian corporation Standa. The stepper motor is driven by corporation Allegro drivers. 


\section{RESULTS}

As concerns the tracking part, we have not tested the profile sensor response to the reflection from the cornea of a human eye. Nevertheless, the response has been obtained from an artificial eye. Figure 4 shows the analog video signals on the data input/output line. It is seen that the output signal does not reach the saturation limit (3.5 V as specified in the datasheet).

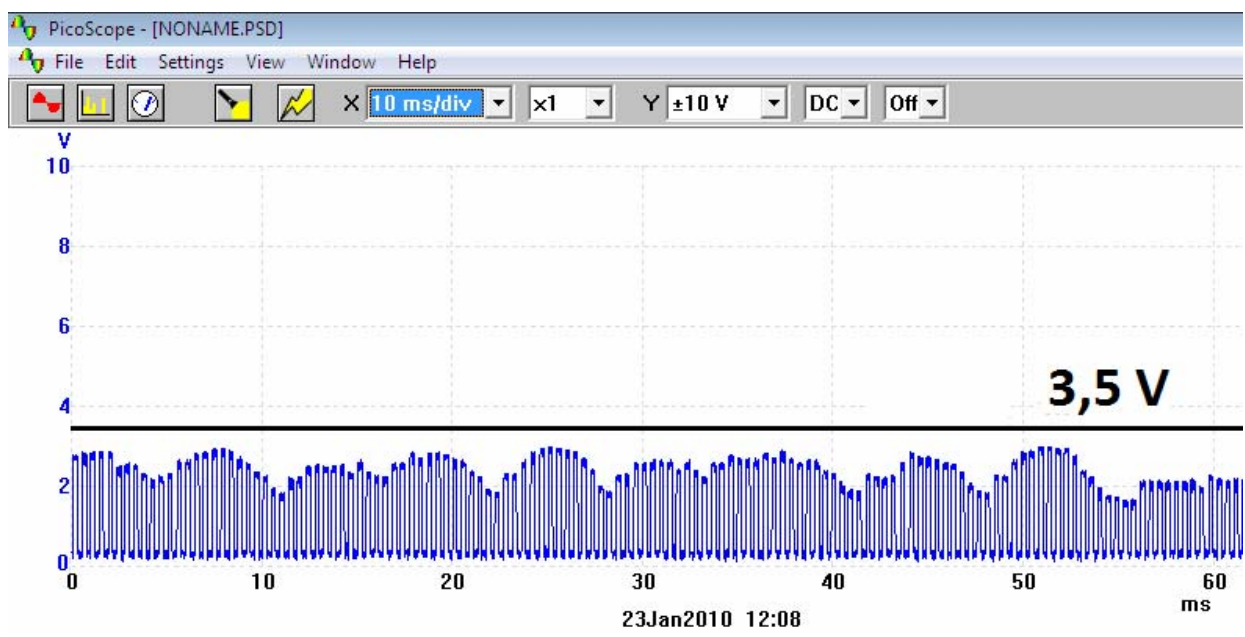

Fig. 4. Output of the linear profile sensor S9226. Each pixel outputs an analog video signal which is read when the trigger line (not shown) falls from the high to the low level. The solid black line indicates the saturation limit (3.5 V).

Electronic circuits controlling stepper motors have been designed and should be joined to the tracking part. During the tests of the stepper motor, mirror M-1 was replaced by a prism. The stepper motor is powerful enough to turn this prism and is expected also to be powerful enough to turn mirror M-1. A video showing a rotating stepper motor with a prism attached to it will be available soon in the website http://www.cfi.lu.lv/optometry/interes/inter_intro.html. Currently, the webpage is under construction. The video also shows the custom-built controller circuits used to drive the stepper motors.

\section{DISCUSSION}

Although this method seems to be rather efficient, it is clear that, in practice, we will possibly face several important difficulties. First, saccades are very fast; they can reach speed of even $800 \mathrm{deg} / \mathrm{s}$, which is well above the maximum speed of mechanical systems. The motorized stages used can provide turnings with the maximum speed of only few deg/s. Thus such systems for compensation of the eye movements would be capable of compensating only slow drift movements of an eye, which is usually not the case. However, performance of these systems could be improved by using high-speed piezo-mounts that can work at frequencies comparable with those of galvanometric systems. Of course, the use of piezomounts requires that the amplitude of saccadic eye movements is reduced as much as possible during fixating the target because such piezo-mounts can introduce very small corrections of optical alignment into the system. 
As the used profile sensor is linear, it is clear that the tracking and compensation of eye movements can be realized in only one dimension. However, the direction of saccades is not restricted to only one dimension, because an eye can freely rotate around its three axes. Thus, a two-dimensional profile sensor is required (and is also available: S9132, provided by Hamamatsu) [3]. However, we have refused the idea to develop the eye tracking part based on this sensor because the availability of PLCC sockets is problematic for this type of IC packages.

It should also be taken into account that the head movements interfere with the eye movements thus reducing the efficiency of the system for eye movement compensation. One of the most efficient methods of how to reduce the head movements is to use the so-called bite bars, which have been shown to significantly fix position of the head [4].

The tracking part may be used in conjunction with other methods for determination of the gaze direction. For example, electro-oculography may also be employed as a tracking method. However, its accuracy is only $1.5-2$ deg., so the noise must be filtered in order to achieve the accuracy needed for AO systems.

\section{CONCLUSIONS}

The method being developed cannot compete - due to its low speed - with current methods; however, the idea behind it may work well. In particular, to increase the speed, piezo-mounts are required. The head movements should also be taken into account. Otherwise, these may compromise the benefits of eye movement compensation.

\section{ACKNOWLEDGEMENT}

The research was supported by ESF project "Support of Doctoral Studies at the University of Latvia". Project No. 2009/0138/1DP/1.1.2.1.2/09/IPIA/VIAA/004.

\section{REFERENCES}

1. Hammer, D. X., Ferguson, R.D., Iftimia, N.V., Ustun, T., \& Burns, S.A. (2005). Tracking Adaptive Optics Scanning Laser Ophthalmoscope (TAOSLO). Investigative Ophthalmology and Visual Science, 46, e-abstract, 3550.

2. http://www.farnell.com/datasheets/8753.pdf.

3. http://sales.hamamatsu.com/assets/pdf/parts_S/S9132.pdf.

4. Glanc, M., Gendron, E., Lacombe, F., Lafailla, D., F. Le Gargasson, J., \& Léna, P. (2004). Towards wide-field retinal imaging with adaptive optics. Optics Communications, 230 (4-6), 225-238. DOI: 10.1016/j.optcom.2003.11.020.

\section{METODE ACU KUSTĪBU KOMPENSĒŠANAI ADAPTĪVAJĀ OPTIKĀ}

\section{Karitāns, M. Ozoliņšs \\ Kopsavilkums}

Optiskās izšķirtspējas uzlabojums, pielietojot adaptīvo optiku, stipri samazina acu kustības. Kaut gan iekārtas acu kustību kompensēšanai ir jau izstrādātas, 
tās ir loti sarežğîtas un dārgas. Mēs attīstām jaunu metodi acu kustību kompensēšanai. Šìs metodes pamatā ir radzenes atstarojuma uztveršana ar lineāra profila sensora palīdzību. Elektroniskās shēmas, kas vada atstarojuma sensoru un soḷu motorus, jau ir izstrādātas. Turpmākā gaitā jāizstrādā shēma, ar kuras palīdzību profila sensors kontrolē soḷu motoru. Viens no šîs metodes trūkumiem ir soḷu motora lēnā darbība. Vēl viens trūkums ir tas, ka profila sensors strādā tikai vienā dimensijā. Šīs problēmas ir novēršamas, izmantojot divdimensionālu profila sensoru un pjezostiprinājumus, kuru ātrdarbība ir daudz lielāka. 